\title{
NEW LIFE OF ICONS IN ARCHITECTURE: APPLICATIONS VERSUS SYNTHESIS
}

\author{
Jerzy Uścinowicz \\ Unit for Architecture of Local Cultures, Faculty of Architecture of Bialystok University of Technology, \\ Grunwaldzka str. 11/15, 15-875 Bialystok, Poland \\ E-mail: jus@pb.edu.pl
}

Submitted 23 November 2010

\begin{abstract}
Poland, as cultural and religious borderlands which are now, as in the past, a part of Latin, West Roman-Catholic, GreekSlavic and East Orthodox culture, is a good place to apply comparative analyses of art of both Christian Churches: Eastern Church and Western Church.

This paper presents selected examples of interaction between architecture, iconography and theology in contemporary sacred art of the last decade in Poland. It also shows the process of evolution of traditional spatial and functional structures and application of new iconography conventions in the Orthodox temples. It covers problems in art as well as new essential ideological aspects of symbolical and liturgical nature.

The effects of design and creation work, presented in this paper, serve as a basis to classify these objects as traditional. This assessment of the synthesis of art achieved here - being always the basis for creating the liturgical mystery play within the Orthodox Church - is left to the reader himself ${ }^{1}$.
\end{abstract}

Keywords: iconography, sacred architecture, symbolism, orthodox, temple, tradition, innovation, synthesis.

\section{Introduction. Return of the icon}

True icons ${ }^{2}$ descend from the heavens. That is and will be the rule of God - downwards as opposed to sideways. Lately however, more or less frequently over the last hundred years or so, icons traverse the world sideways as well, from East to West. The reasons for these journeys were of various sorts as were the journeys themselves of a more physical than spiritual nature - nevertheless they became a fact. Icons out there are in abundance in present times. The icon itself became a common property of the whole Christian Church.

\footnotetext{
${ }^{1}$ Translated by Mateusz Sochon.

${ }^{2}$ Theiconinart,lies exclusivelyin the domain of painting ([eikôn] $=$ gr. image, portrait) and is out of necessity anthropological. As stated by rev. Grzegorz Krug: "According to tradition, an icon may be only that painting, which represents a face, even more so a human face transformed by the Light of God". This orients the function of iconography towards specific forms and subjects connected with anthropological notions (Krug 1981: 29).
}

Such journey of the icon in so many directions would not be possible without its rediscovery in the East. Signs of its return as a cult object and presentational art phenomenon can be seen as early as the beginnings of the 20 th century, when an icon ceased to be - as it was in the past named - a "black board", even before Kazimierz Malewicz placed his famous "black square" as it were an icon, in the "beautiful corner" of the room. It ceased to be "black", when the Holy Trinity by Andrei Rublov, after being wiped clean of its historical dust, restored and renovated, exploded in a feast of colours yet unseen. It could be seen now, owing to the work of conservators, freed from the layers covering it throughout the years. Once again it became the "window to eternity", a glimpse into the other world. There was no "curtain" covering it any more. There was no black. There were, instead, all the colours of the world. We could yet again "contemplate it in colours" (Трубецкой 1976). 
Because of the "rediscovery" of the icon and its consecutive journey through its native Eastern Orthodox world, both the Christian East and West became artistically prepared to receive it. Theological preparations were in motion as well, mainly due to - written mostly in western Europe ${ }^{3}$ - fundamental treaties of Jewgienij Trubieckoy, rev. Sergiusz Bulgakov and rev. Pawel Floreński or the later treaties of Leonid Uspieński and Paul Evdokimov and others. They unveiled the "secret life" of the icon, not only as a unique and sublime art form, element of culture and the history of Church, but also a phenomenal philosophical and theological beacon. The icon has proven its "ability to speak". Just as text in its semiotic transmiting principle ${ }^{4}$, so did the icon, through real symbols of the supernatural reality of the world of God, hand us a testament of this world and the struggle for Salvation anew. This testament has proven itself to be predominant over the many other ways of expressing spiritual aspirations of $\operatorname{man}^{5}$. Soon everyone found it out. It was not only through the newly discovered colours, although they might have been responsible for this unveiling. The inverted perspective, the geometrical abstraction, symbolism, multitude of layers and space-time perception - are only some.

Is this return of the icon to sacra interiors permanent? Does it change anything in the present situation

\footnotetext{
${ }^{3}$ To this day the Institut de Theologie Orthodoxe Saint-Serge in Paris prepares for this.

${ }^{4}$ As it is commonly known - icons are written like words, not painted. Writing icons is a semiotic rule of aesthetics, not aesthetic itself.

${ }^{5}$ After the successful battle over icons, after the Quinisext Council (in Trullo), the seventh Ecumenical Council, and also the Council of year 860, where the equality of the Word of God and the icon was confirmed dogmatically, a tendency in the Eastern temples may be observed, to transfer the symbolic images from architectural elements onto iconography. Since then, all paths of symbolic expression through art are equal and complimentary. Architecture, iconography (frescos, mosaics and icons), the arts of light and all others are complimentary and create a "wholesome" image in a temple. The Orthdox tradition has never limited artistic forms of expression. This is also true in the case of sculpture. Due to its spatial qualities, it has been perceived as an art form far more difficult to master, too direct and naturalistic when the anthropological aspect is concerned. It has more difficulty in "entering" the Godly planes, for the symbolic form will forever be burdened by matter and will be too encumbered by it to step out of the material sense (in contrast to the icon whose materialization is impossible due to lack of mass and volume and "evocates a shining presence far beyond its point of origin" (Evdokimov, p. 285). Therefore it is not a form in common use, albeit it is not depreciated as well.

${ }^{6}$ Everything within the icon is symbolic: the colour, line, spot, composition, etc. It is a peculiar information code, expressed in art form. According to M. Bułgakow: "In principle everything within the icon is a symbol and possesses a specific meaning: not only the content, but also the form and colour" (Bułgakov 1987, polish transl.; 1992, przeł. Henryk Paprocki, s. 158).
}

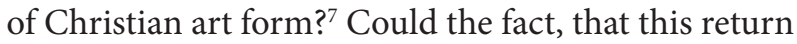
permeates with such intensity in Poland - the border between the Christian East and West, influence the state of present art? Somehow change it and become grounds for setting a proper course for eastern iconography, in its present co-existence with the orthodox temple architecture?

Tracing some of the examples of iconography in orthodox churches of today, may be helpful not only with assessing the state of consciousness of the present day Eastern Orthodox Church. It can not only depict this state in the cultural-religious borderland, but also in the whole church - the one divided between the East and the West. It is this division, that best stresses the problems and identifies them. What distinguishes itself most vividly, may be partially extrapolated to the whole of the church and may be used to gain wisdom.

\section{New life of the icon}

Just as discoveries made by conservators on the brink of the $19^{\text {th }}$ and $20^{\text {th }}$ centuries allowed us to see the icon free from layers and repaintings covering the Archetype, so did the rediscovery of the icon, not only for the Orthodox world, but also the Christian and Protestant and the whole oikumene, begin on polish grounds by hand of often mentioned in my studies Jerzy Nowosielski (Uścinowicz 2009). Nowosielski however is done with his icons. He does not write them anymore. He left hundreds or maybe even thousands of them in churches. He left behind not only his artwork, ingenious both in their iconographical-theological and architectural value like the dimensional creations in the church in Wesola, or orthodox churches in Bielsk Podlaski, Górowo Iławeckie and Biały Bór, but also hundreds of sketches and unfinished projects. With their great potential, they are the live tradition of polish sacral art. This tradition is in some manner continued by the orthodox school of icon writing - Iconographical Study at Archangel Michael's parish in Bielsk Podlaski, which is led by a charismatic minister, father Leoncjusz Tofiluk.

The study exists since 1991. It is the only icon writing school in Poland. Subjects taught here are amongst

\footnotetext{
According to Leonid Uspienski: "Simultaneously both the East and West unveiled the dogma of the cult of icon, sealed by the blood of martyrs and faithful" (Uspieński 1987: 8-9). The victory over iconoclasm was an effect of the common struggle of the Roman Church and Eastern Patriarchs. Taking the argument further - it could be said it was the roman pope who saved the icon from iconoclasm. How did it happen then, that after the iconoclasm, after the seventh Ecumenical Council, evolved in Europe two art forms in such opposition to each other, expressing the same Revelation? How could this be, that in truth the Christian West did not accept the icon? (Uspienski 1980, polish. issue;1991)
} 
others iconography, theology of the icon, sacra architecture, and history of the church. The Old and New Testament scriptures, liturgics, history of art, old church Slavic language and Greek are also studied. The school resides in an old wooden building, formerly a hospital, later a kindergarten, a building somewhat decrepit but being consecutively restored. It consists of a lecture hall, small library and 3 small icon writing workshops. A small chapel was attached to the longer axis of the construction, in such a way that the existing room used as a gallery of icons done by students and as a place of final examinations, would serve as a temple nave - a pronaos - on a daily basis.

\section{Orthodox Holy Trinity Academic Chapel in Bielsk Podlaski}

This tiny Orthodox Church ${ }^{8}$, built on a square measuring a symbolic $3 \times 3$ fathoms, was built in the name of the Holy Trinity. It was done so not without a reason. The Trinity is the greatest mystery of Christianity, the most fundamental dogma of faith. And the Holy Trinity icon by Adrei Rublov - the ultimate icon, an unattainable formula and iconic canon. Saint Andrei Rublov, recently canonized saint of the Orthodox Church, is next to St. Lucas the Evangelist, Alipius and Teophanes the Greek -one of the patrons of this school.

The Church is simple - spartan, even puritan - on the outside (Fig. 1). It is limited to only the necessary symbolic forms and meanings. No redundant addings or stylings, just like in the olden, medieval temples of Rublov's times. Despite its size, it is a temple in the full extent of the word. It can serve as a place to celebrate liturgy. It has the traditional altar division - the iconostasis, introducing the traditional divide into the hierateion and naos.

The interior architecture of the temple revolves around the icon and together with it, tries to introduce us to a different, more sacred reality. It avoids shadow, "inverts" the perspective, directs and focuses it on the congregation, just as the icon does. This attempt is supported by the temple's small size and natural light entering the interior from underneath the dome and circular side-windows. The feeling is permeating through the interiors, for as the faithful say: "... it is like you enter

\footnotetext{
${ }^{8}$ Orthodox Holy Trinity Academic Chapel at School of IconWriting in Bielsk Podlaski - architect: Jerzy Uścinowicz; technical assistant: Tomasz Daniluk; struct. engineer: Waldemar Orłowski; client: Leoncjusz Tofiluk priest-rector; paintings: Leoncjusz Tofiluk with students of Academy: Mirosław Trochanowski, Katarzyna Gierasimiuk, design: 1999; construction: $2000-2004$.
}

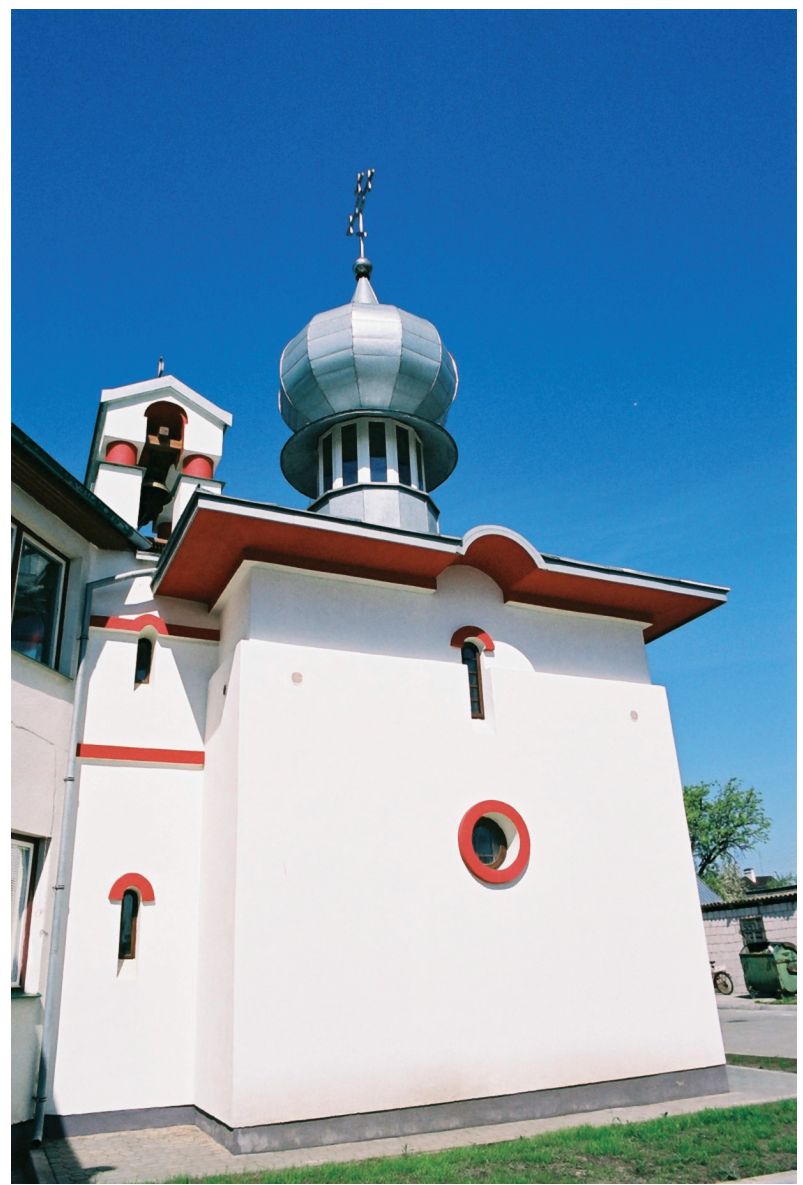

Fig. 1. Orthodox Holy Trinity Academic Chapel in Bielsk Podlaski. General view of the church

an icon and stay there" 9 . And maybe it is so? Or maybe it is just what people say (Fig. 2).

In here, architecture exists together with the icon "at our fingertips". It is the icon that constitutes all the walls, domes and barriers. It strips them of their weight and matter. They are nothing more than mere backdrops for the icons. They are the surroundings of a celebrated liturgy, a resonator for the choir, a shelter for candle fire and incense smoke. They live as they used to, since nothing has changed in here since Christ. Only the number of saints grew. These icons - in the form of polychromies on the walls or individual pieces embedded in the structure of the altar barrier - were introduced in accordance with the canon and iconographic tradition. In the apse's concha, traditionally, an icon of the Holy Mother Orante - Theotokos was placed. Beneath, a scene of the Eucharist and around the whole temple, a procession of saints (Fig. 3). The vault is decorated with a scene of Pentecost on its eastern side and Last

\footnotetext{
9 The temple as a whole is a multielement, ordered structure of sacra space, comparable to - after Saint Dionysius - the Hypericon.
} 


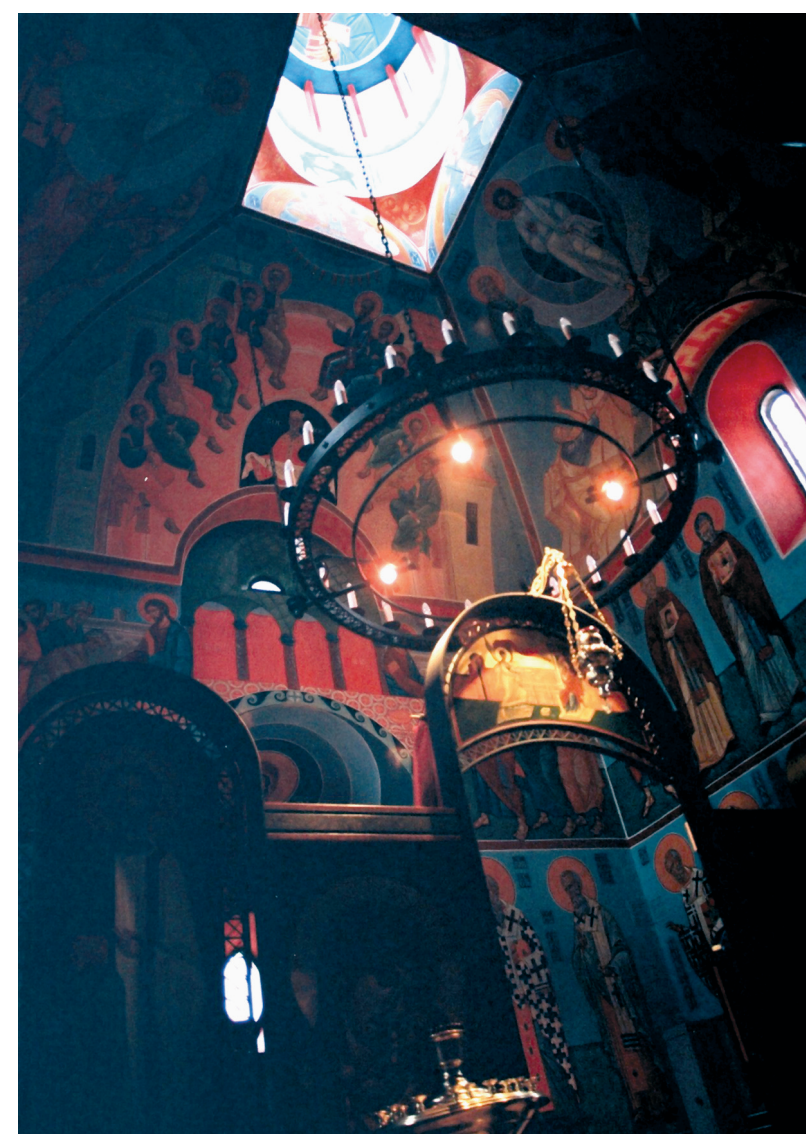

Fig. 2. Orthodox Holy Trinity Academic Chapel in Bielsk Podlaski. View of the interior of the church. Iconostasis, panikadylion and dome with icon of the Christ Pantocrator

Judgment scene opposite. Other, side surfaces bear scenes of Transfiguration, Resurrection as Christ's descent into the abyss. Above, as typical on pendentives, are icons of the Evangelists with their respective symbols, and on the tholobate arches - the Archangels. The whole form is crowned by the icon of Christ Pantocrator placed traditionally at the intrados of the dome. His head is surrounded by a halo with a cross and Greek letters $\mathrm{O} \Omega \mathrm{H}$ : "I am, who I am" (Exodus 3-14). The Pantocrator holds

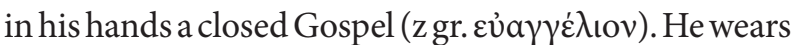
a hiton covered with a blue cloak ${ }^{10}$. He is being carried by the Heavenly Host: Cherubs, Seraphs and Thrones (Fig. 4).

The setting and manner of iconic presentation is a kind of book of faith "in colour", closed, yet not entirely.

\footnotetext{
${ }^{10}$ On the dome around the Pantocrator and the Oranta in the apse concha, according to theological interpretation derived from Liturgy: "gathers all heavenly and earthly creature, destined to become a reborn creature in Christ, the God Human" ((after:) Leonid Uspienski, La Théologie de l'icône (...), p. 172). The whole universe "condenses" under the dome of church, over which reigns the Pantocrator, as in the words: "All authority has been given to Me in heaven and on earth" (Matthew 28: 18; Grabar p. 374-375).
}

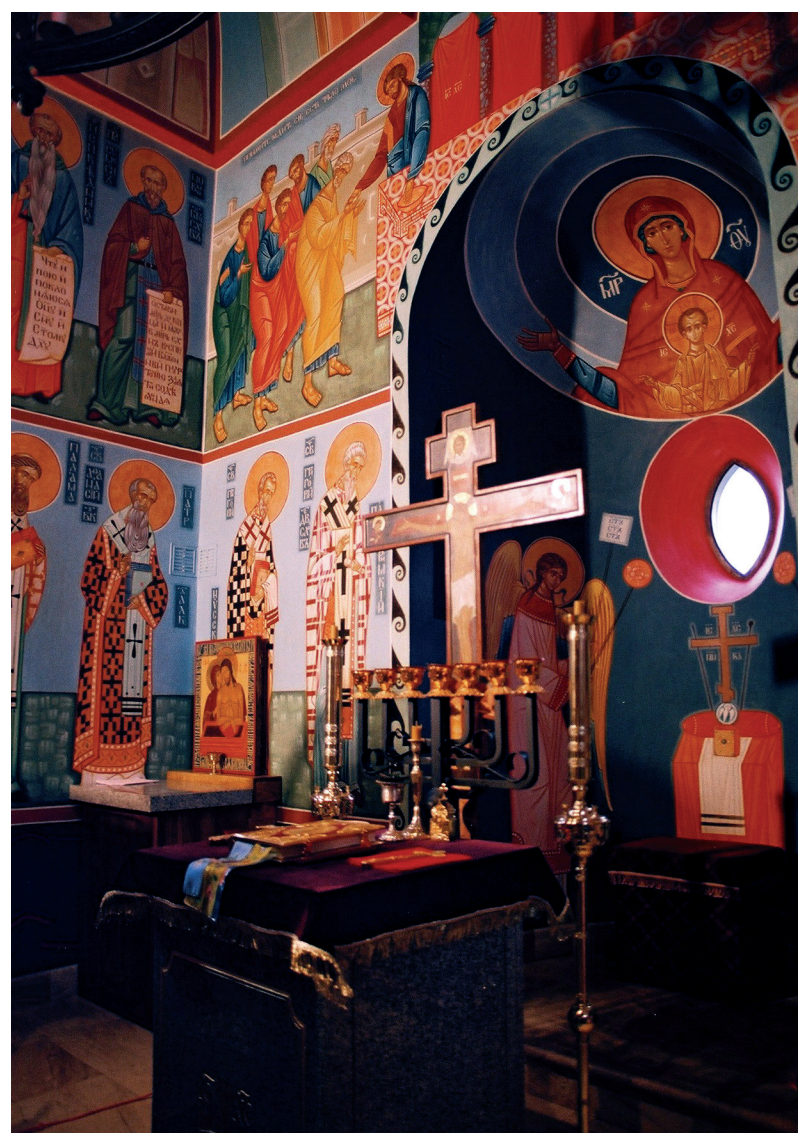

Fig. 3. Orthodox Holy Trinity Academic Chapel in Bielsk Podlaski. View of the interior of the chancel space. Altar and apse with icon of the Virgin Mary Oranta

The world of the icon does not however end inside the temple. It reaches outside temple walls as well. The lines of the three walls have been treated as three rows of a classic iconostasis: Deesis, Prophets and Patriarchs. Due to the small size of the church they are not inside. There would not be enough room. Thus they were lead outside, beyond the "frames" of the building, like halos of saints in icons. They form a sort of external iconostasis, which combined with the Pantocrators visible through the windows enters a world beyond the temple. In its principle message there is not only the promise of "kingdom come" within the temple, but also outside, in the everyday world of man, heralding the second coming of Christ. The innovation here is limited only to the form, not the message it contains (Fig. 5).

A sort of formal innovation is a glass intrados, which "since forever" was to bring the most light into the temple. Its role was not only to mark the Eucharistic center of the temple but also or even mainly illuminate the icon of Pantocrator. It is through this light, its strength and angle of reflection, that the "squaring of the wheel" - "transformation" of the geometry of the circle into the square and back, is 


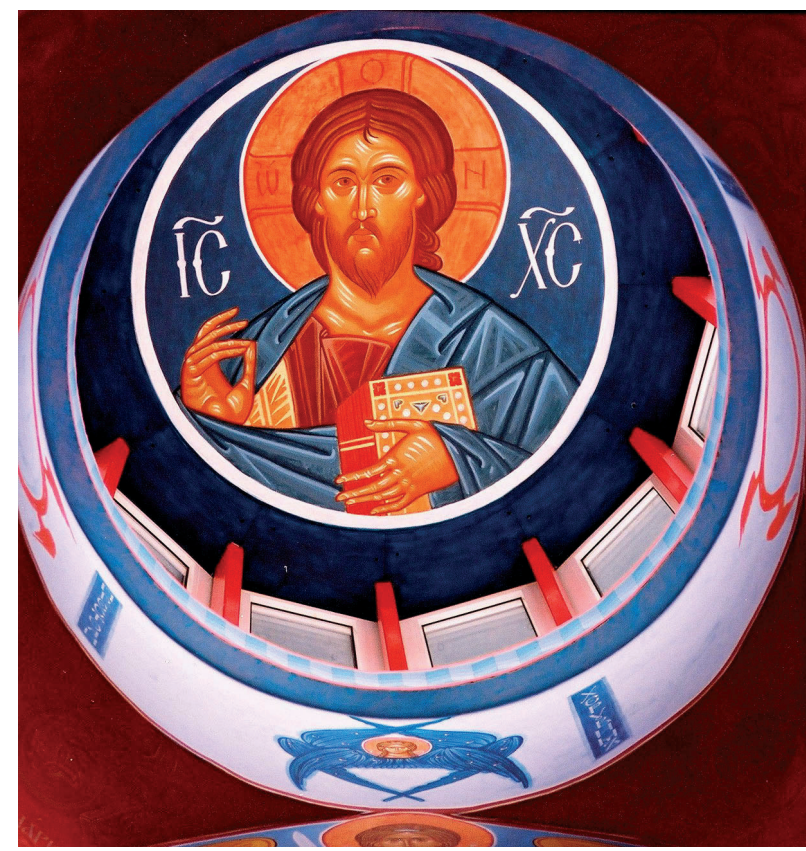

Fig. 4. Orthodox Holy Trinity Academic Chapel in Bielsk Podlaski. View of the glass tambour and dome with icons of the of the Christ Pantocrator, Cherubs, Seraphs, Thrones and Archangel

visible, as a synthesis of Heaven and Earth symbolized by the two figures.

The apse window is an innovation itself - resembling the shape of a Mandorla ${ }^{11}$ from the icons of Christ along with its spiritual symbolism of the perfection of the One who shines down on us. Innovative is also the redness of the internal edges of walls and the roofs with their moldings and eaves, which carries equally important godly symbolism.

The outer shell stands for very little in Orthodox Churches, its meaning being only "temporary", like a prayer being only the path to internal and spiritual change. This is how it has always been in the Orthodox East, from enormous Constantinian and Justinian cathedrals like Hagia Sophia or Hagia Irene in Constantinople, to small "mud huts" and hermitages of Cappadocia, Sinai and Crimea or caverns of Pskov and Kiev. It has its roots deep in the local orthodox church architecture of Podlasie. However it also reaches out, though indirectly, to the still present in the area architecture of orthodox churches of Veliky Novgorod and Pskov and to the churches of Lemkos and Moldova, with their outward eaves shielding the paintings placed on exterior walls (Fig. 6).

\footnotetext{
${ }^{11}$ Mandorla - also known as vesica piscis (Italian for almond) - is a sort of halo in the shape of an oval (ellipsis or two intersecting circles) clasped on both poles with an ogive. It symbolizes, in iconography, the spiritual perfection of the characters it surrounds (most often Jesus Christ and the Holy Mother of God) (Znosko s.170)
}

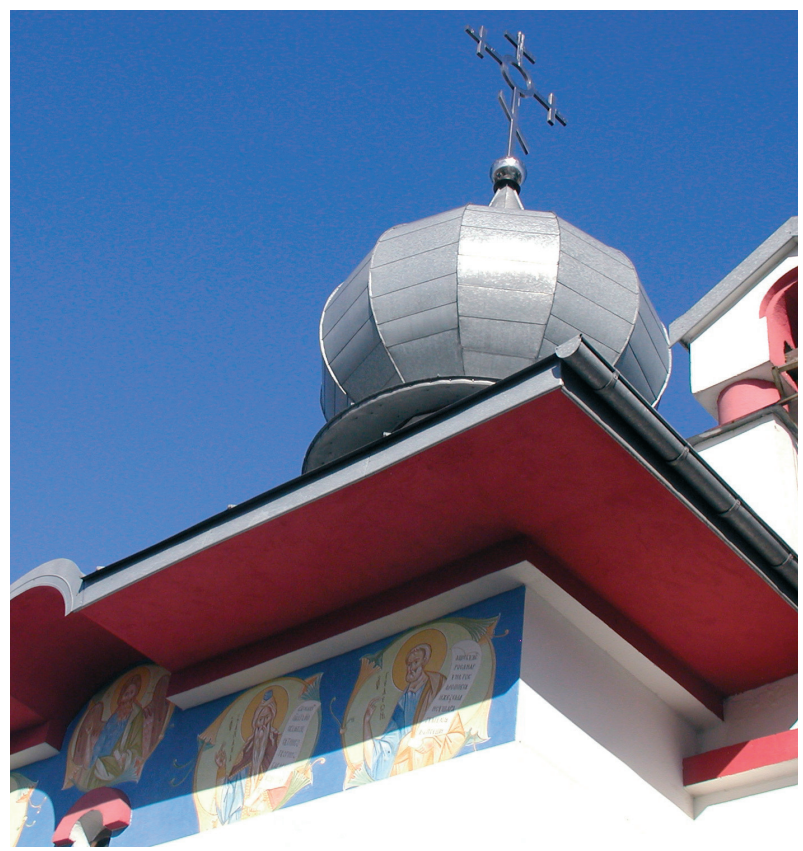

Fig. 5. Orthodox Holy Trinity Academic Chapel in Bielsk Podlaski. View of the roof dome and belfry. Detail of the quoin

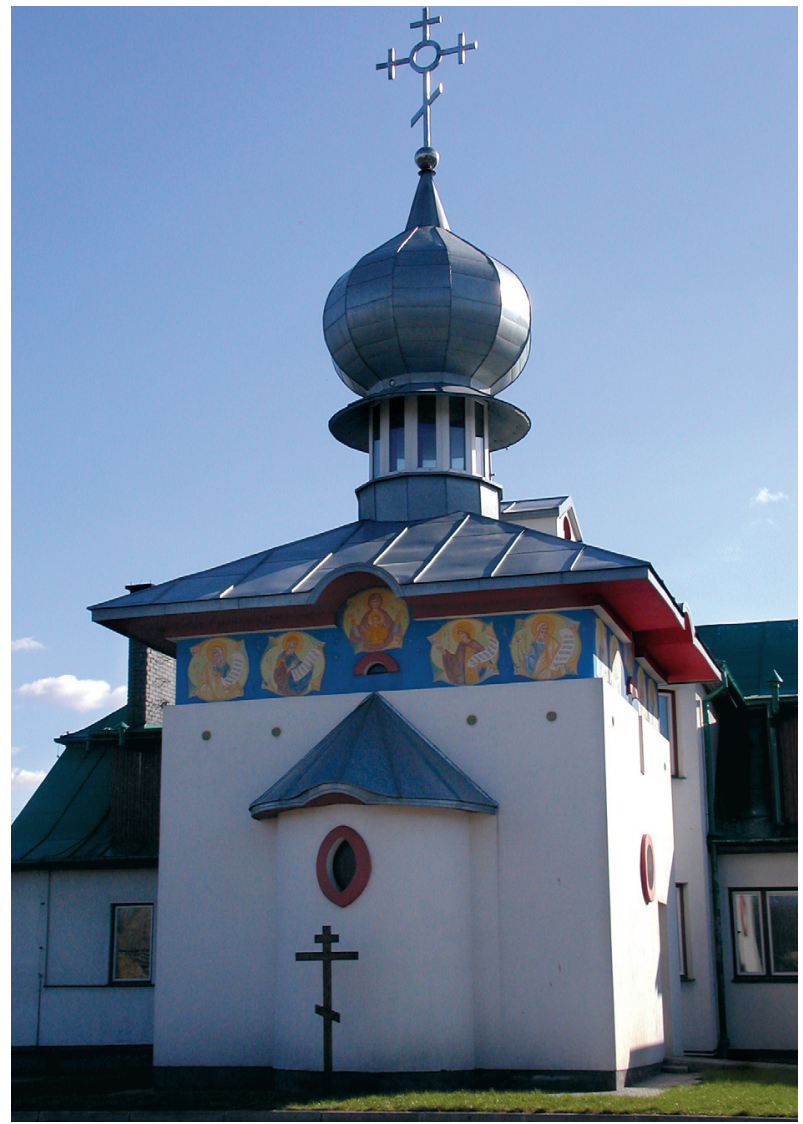

Fig. 6. Orthodox Holy Trinity Academic Chapel in Bielsk Podlaski. View of the chapel from the east side. Three rows of an external iconostasis: Deesis, Prophets and Patriarchs outside the temple 


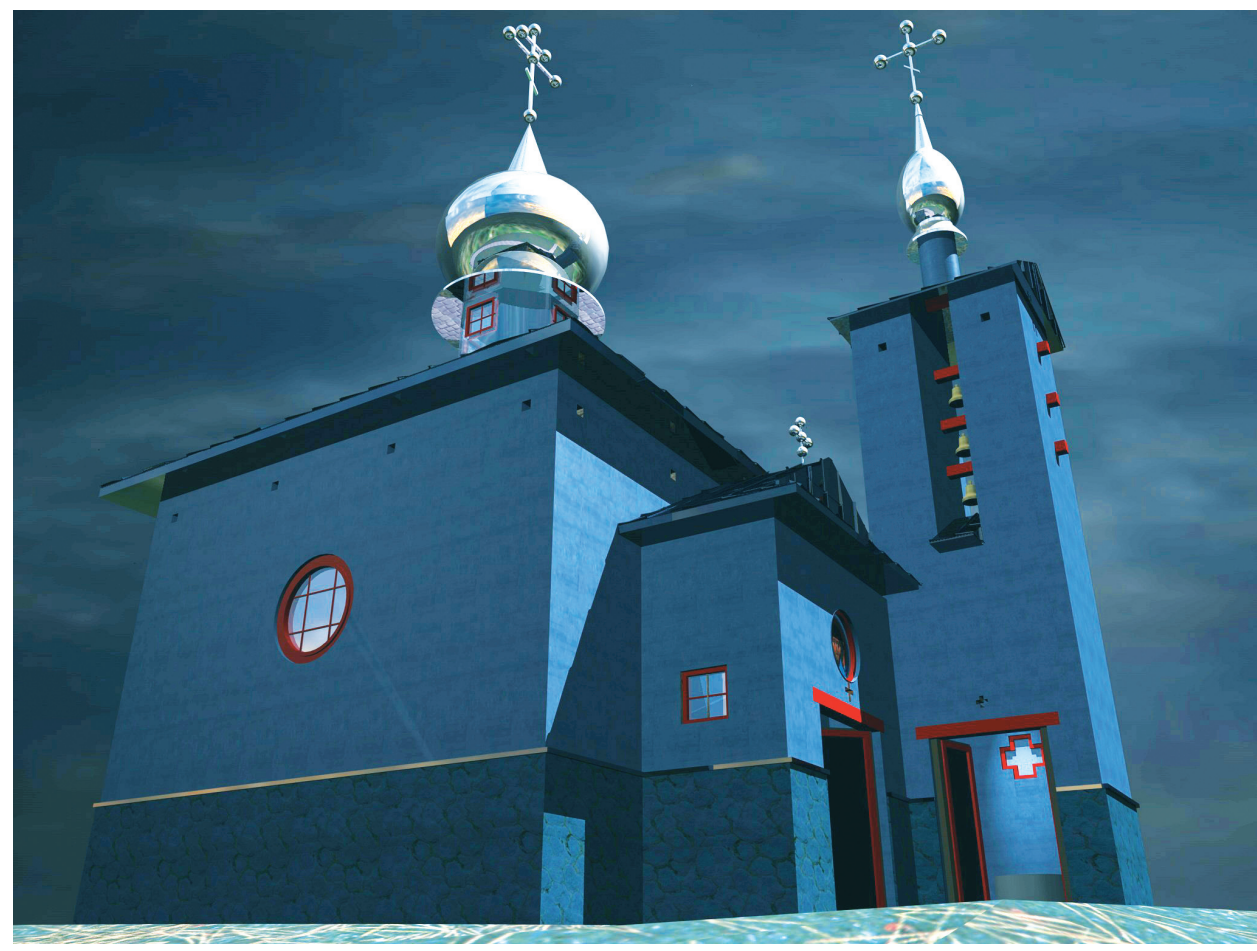

Fig. 7. Church of the Holy Resurrection of Christ the Lord in Bobrowniki. Project of the church. Architect's drawing

\section{Church of the Holy Resurrection of Christ the Lord in Bobrowniki}

A form taken directly from the church of the Holy Trinity is the cemetery chapel of the Resurrection of Christ the Lord in Bobrowniki ${ }^{12}$. It has the same simple, restrictive, cubic tectonics of small size. It's a transposed model of the traditional monoapse, domed temple. It relates to the local, traditional architecture of Podlasie. It does so through reference to local form, as well as natural colour scheme, utilization of native materials, details, proportions and scale. It is also clearly embedded, both stylistically and formally, in orthodox church architecture of the Polish-Belarusian-Ukrainian borderlands specifically (Figs. 7, 8).

Inside, one may observe a clear division into the hierateion (presbytery), naos and narthex. Before the narthex, on the southern side, the belfry is situated. On its lower level there is a small chapel with a well for celebrating water sanctification service during the Epiphany in Jordan.

The twin division of the temple into the naos and hierateion is not unambiguous. It is more of a "dialo-

\footnotetext{
${ }^{12}$ Orthodox Church of the Holy Ressurection in Bobrowniki, architect: Jerzy Uścinowicz, design of structure of polychromy, iconostasis, polycandilion, altare: Jerzy Uścinowicz; structural engineer: Helena Maliszewska, client: Roman Kiszycki, priest, Design: 2006 / Construction: 2006-2009.
}

gue". The single row iconostasis is low and open work. It is formed of three red arches, resembling royal and deacon door with four sovereign icons. This solution, relating to developing forms of early altar barriers (transitional between the templon and tableau) opens a possibility for the area and liturgical dialogue between both sides of the temple - "the saint of saints" and "the saint". The iconic row of Deesis, representing heralds of man, necessary to unveil the true theological meaning of the iconostasis ${ }^{13}$, was situated on the sub-vault belt surrounding the temple. The main icons

${ }^{13}$ The origin of iconostasis in Russia was the appearance of the Deesis icon, which was once dubbed the whole iconostasis. The Deesis scene expresses the belief in the power of a thanksgiving prayer addressed to God through his highest advocates - the Holy Mother of God and Saint John the Baptist (Prodromos). It always was the main content of the iconostasis. It expressed the dogmatic purpose of the Advocates. Expanded by the addition of Archangels, Disciples and Saints, it crystallized the need for common prayer, with individual characters oriented towards Christ the Pantocrator. By becoming the fundamental and slowly expanded element of the iconostasis - both the formal and ideal center of the orthodox temple - it culminated its meaning. Owing to eschatological references, embedded at its liturgical roots, the Great Deesis entered the extensive Final Judgment. Through this, it expressed the faith in the power of the highest advocates in front of Christ of the second parousia. In the context of the Descent of Christ into the Abyss and The Resurrection of the Lord, the Deesis scene has an exceptional eschatological meaning. It becomes the link between the icon of Final Judgment on the western wall and the icons of Holy Mother of God Theotokos and Eucharist depicted in the apse. 
of Christ, Theotokos and John the Baptist are placed in the apse. Christ is presented as a Mandylion in a circular mandorla, as a stained glass "eastern window". $\mathrm{He}$ is an element of the iconographical composition representing the Mother of God, towering in the apse. In front of Him, as a traditional ante-altar cross, the crucifixion scene is situated (Fig. 9).
Deesis is further iconographically developed into the side walls of the apse, the eastern wall of the hierateion and side walls of the naos. In order, it represents the archangels Michael and Gabriel, on both sides of the Deesis, Saint Peter and Paul the disciples and the Holy Fathers of Church: Basil of Caesarea, Gregory of Nazianzus and John Chrysostom. Posed to resemble a

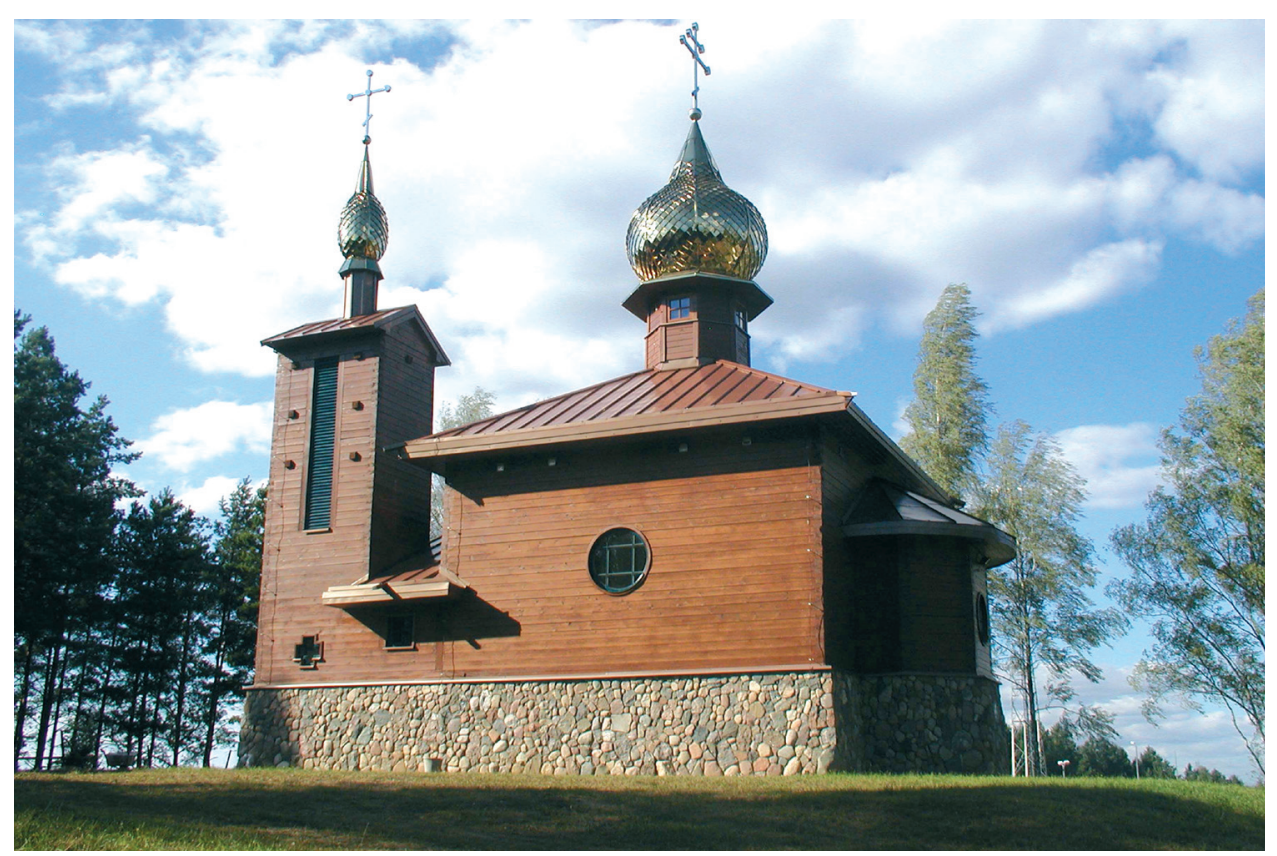

Fig. 8. Church of the Holy Resurrection of Christ the Lord in Bobrowniki. General view of the church from the south side. Realization

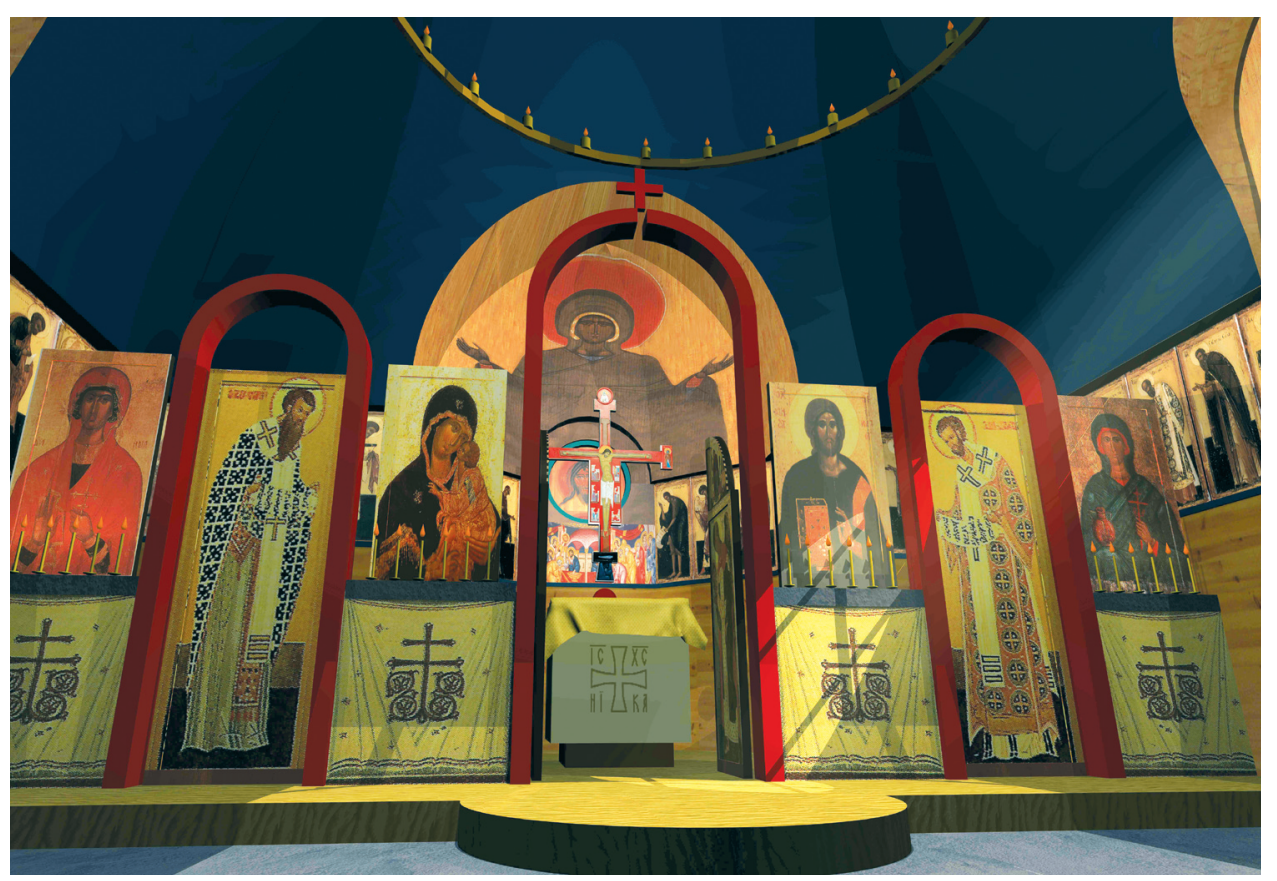

Fig. 9. Church of the Holy Resurrection of Christ the Lord in Bobrowniki. Project of the iconostasis, altar, crucifixion and iconography structure. Architect's drawing 


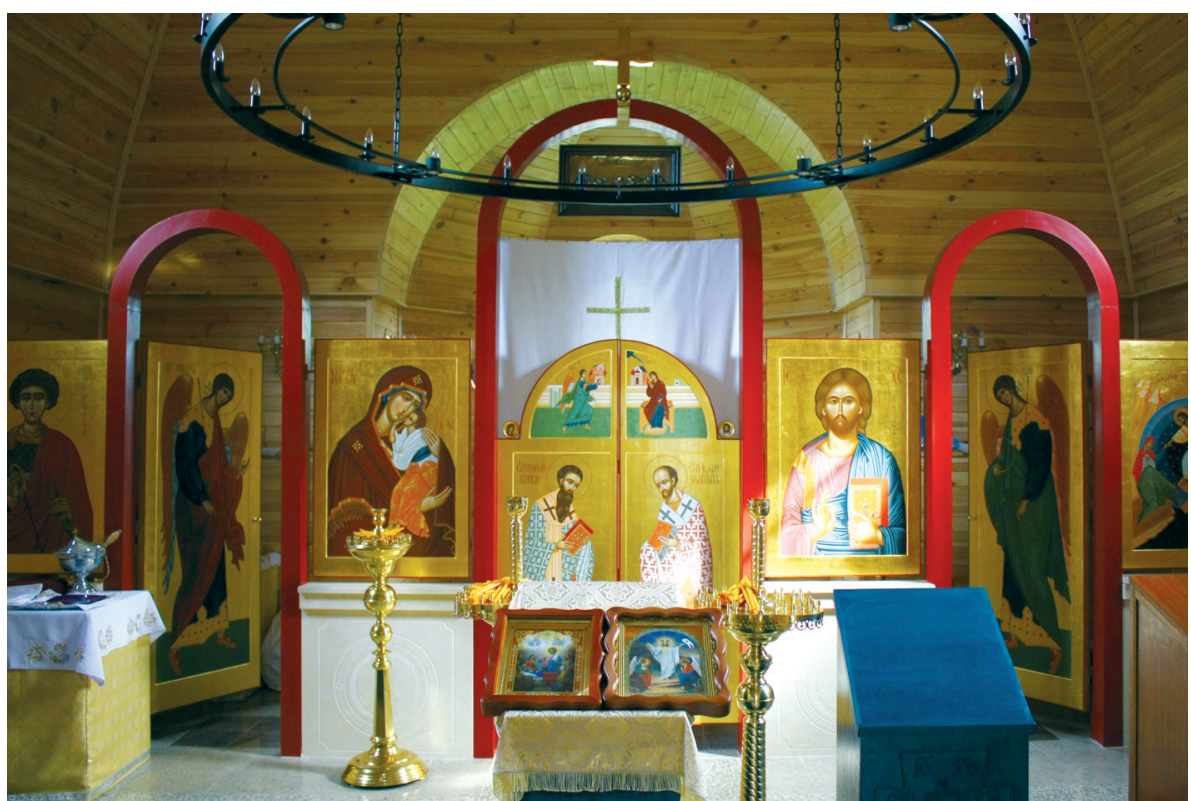

Fig. 10. Church of the Holy Resurrection of Christ the Lord in Bobrowniki. Interior of the church. View towards the altar and iconostasis. Realization

prayer to God, the Deesis continues to represent a procession of disciples, great martyrs and saints of Church, both common and local. In this manner, by creating an overlap in the design of the iconostasis and the iconography line surrounding the temple, the theological fulfillment of the iconostasis itself as a barrier-link has been achieved, as well as their growth from the center into the whole temple. In comparison to known historical representations, this seems to be an important innovation developing traditional iconographical models (Fig. 10).

The vertical utilization of the interior, is stressed mainly by the central dome and a cloister vault covering the naos, with four lunettes. The vertical axis, culminates in the dome where an icon of Christ the Pantocrator is planned to be placed on the intrados. It intersects the horizontal axis of the building at the pulpit, the Eucharistic center of the temple.

\section{Church of the Holy Resurrection of Christ the Lord in Bialystok - Słoneczny Stok}

On the other edge of the spectrum, with an immensely developed structure and of incomparable size to the others, is the Orthodox Church of the Holy Resurrection of Christ the Lord in Bialystok ${ }^{14}$.

\footnotetext{
${ }^{14}$ Orthodox Parish Church of The Holy Resurrection of Christ the Lord in Białystok-Słoneczny Stok - architect: Jerzy Uścinowicz; structural engineer: Władysław Ryżyński; client: Andrzej Bierezowiec (1988-1989), Włodzimierz Cybuliński, priests; design: 1991-1992; construction: 1993-2006.
}

This is a church of a distinctive inward composition (Fig. 11). It was built as a shape of two overlapping figures - an octagon and Greek cross. It is cosmologically oriented to the so called "winter" east. It is divided into three by a three-part presbytery, naos and narthex. The liturgical section is expanded in the north by an octagonal baptistery, above which a belfry is situated.

The interior is formed by a heavily sculpted, circular vault structure of reinforced concrete (Fig. 12). It is lead out of the poligonally shaped temple walls and transforms gradually into a geometrically simple crossing of barrels rising upwards, capped with a dome resting on pendentives. The dome is hanged in the center, completely separated from the vaults with four light arches. They raise the dome - as in all the orthodox churches built after the iconoclasm - towards its "supraheavenly" status and form. Unlike other examples - it does not rest on any kind of tholobate, but "floats", attached to a supporting construction above it. Although the principle of lifting the dome by means of light entering through the sub-dome tholobate is traditional in the orthodox religion, a complete separation of the dome from the supporting construct and hanging it from above is an innovation (Fig. 13).

A deviation from the traditional dome structure, where the dome crowns over the temple and closes it from above with an icon of the Pantocrator, is a square opening cut in the intrados. It allows the light to enter the temple through a skylight-lantern, being the tholobate of the central dome. This solution is an analogy 


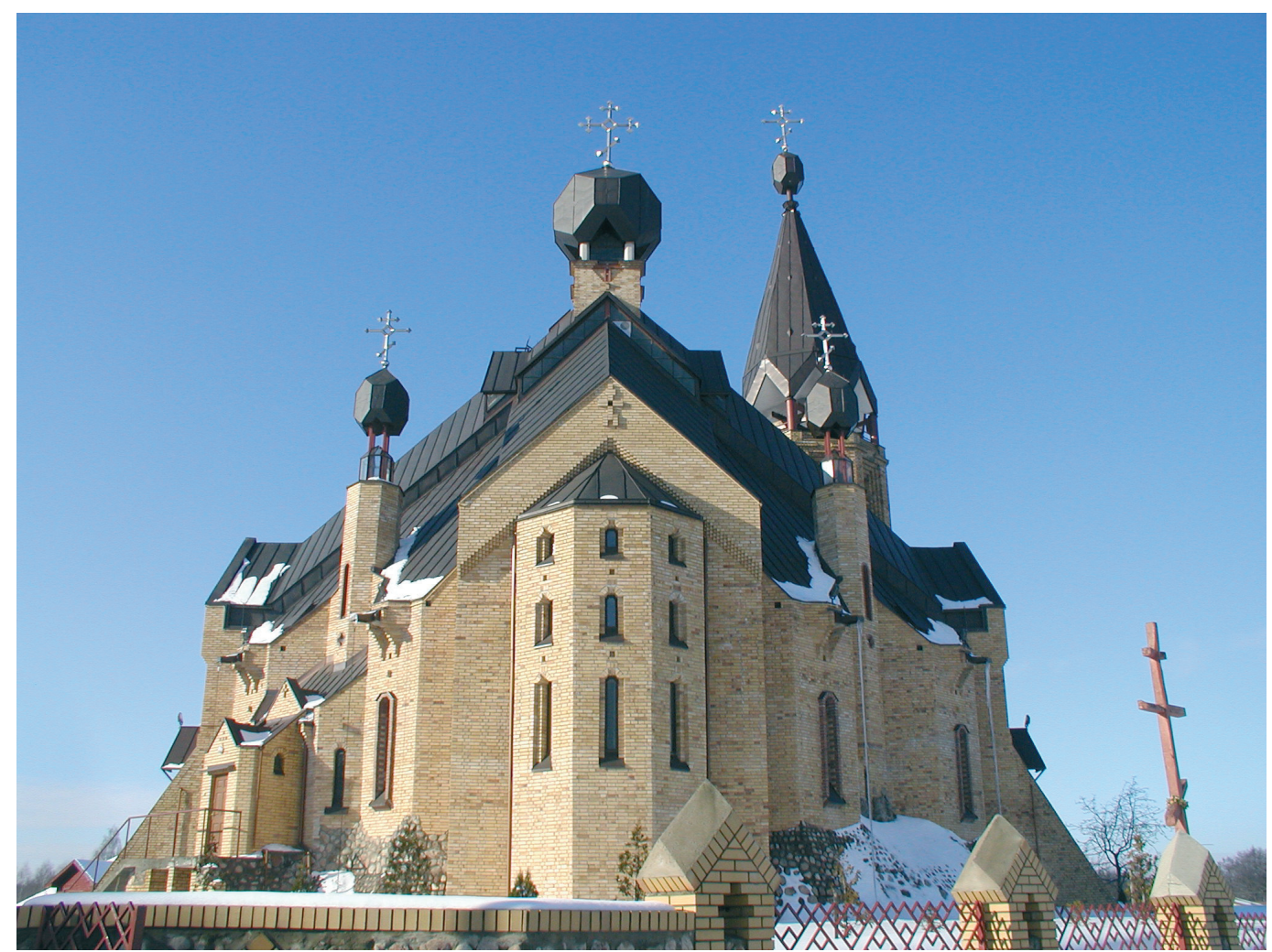

Fig. 11. Church of the Holy Resurrection of Christ the Lord in Bialystok - Słoneczny Stok. General view of the church from the east side

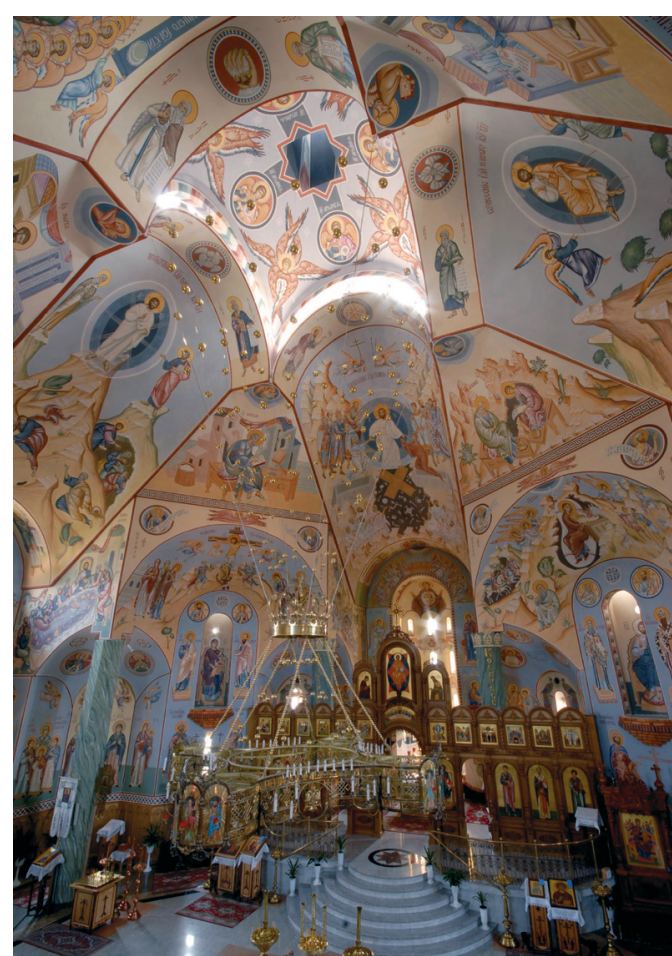

Fig. 12. Church of the Holy Resurrection of Christ the Lord in Bialystok - Słoneczny Stok. Interior of the church. View towards the altar. Space structure and iconography

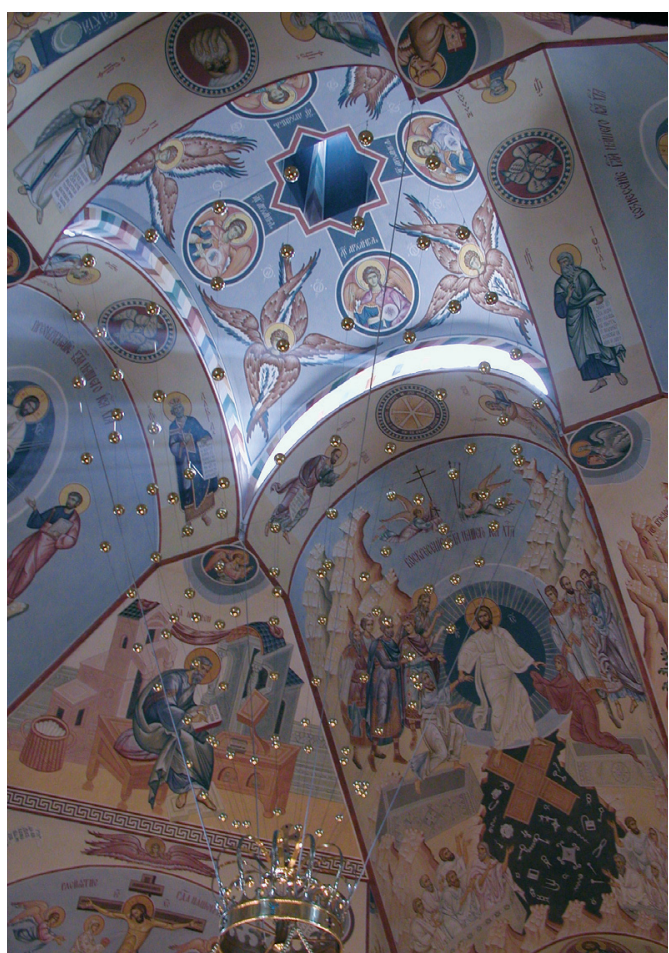

Fig. 13. Church of the Holy Resurrection of Christ the Lord in Bialystok - Słoneczny Stok. Interior of the church. View towards the dome structure 
to the Anastasis of the Basilica of the Resurrection of Christ the Lord in Jerusalem, the temple being a name reference and the protoplast of the Bialystok one. There, as well, the dome covering the chapel has at its intrados an oculus opening into the "prophecy of eternal life". This caused in turn obvious changes in the iconography, which substituted the image of Pantocrator for a Greek cross with an eight-pointed star in its middle, and Archangels in medallions at each arm's ends. It is surrounded by Old Testament subtle beings - Seraphs, Cherubs and Thrones. A ray of light enters the temple from the crystal-capped dome through this very star figure. By doing so it marks the center of the dome, the temple and the world - omphalos and its main axis axis mundi.

As the geometry of the octagon, the prime figure used in designing the shape of the temple may be also linked to the eight-point star, connecting them with one typological notion and setting them in an eschatological perspective to the Resurrection is obvious. The star is therefore the "Star of Bethlehem" and at the same time the church itself, which as the "guiding star" points the way towards salvation - eternal life of the "eighth age" in the "eighth heaven".

The fillings between the barrel vaults form multiple conical and cylindrical surfaces, quarter- and halfdomes. The whole is resting on four intersecting frames of reinforced concrete, placed on eight columns. This construct also supports the roof and the whole internal and external finial - the tholobate and the "crystal" dome.

The central part of the church marked by the eight columns, is surrounded by a crown of apses, allowing for the separation and personal prayer of the faithful, as necessary in the orthodox church as the common Eucharistic liturgy. The idea refers to its prototype the Basilica of the Resurrection of Christ the Lord in Jerusalem, with its multiple chapels and other places for Christians of various faith.

The iconostasis divides the temple into the hierateion and naos. It varies from the original design. It was to be of two rows, with a low templon, an iconographic creation, not a decorative sculpture, as it came to be. The central panikadylion, which was to be a circular choros of candles, came to be of reasons unknown an exceedingly eclectic chandelier. Not unlike the baptistery, above which a pendentives supported dome and a musical choir were completed. It was later however separated from the space by a flat ceiling, as it attained a more "useful", new function of a victimaire (sic!).
The architecture of the interior corresponds closely with the iconography. It fills neatly all the walls and vaults, neutralizing the existence of any independent tectonic forms. In the apse concha an icon of Theotokos the Holy Mother - was placed. Above, in the indents of the cross, one can see a central Resurrection scene as the Descent of Christ to Hell and opposite, to the west: an icon of the Final Judgment, and next to that: Ascension and Transfiguration of Jesus. Between the arms of the cross, diagonally, images of Saint Evangelists and their symbols are situated, and below them, on conical surfaces, icons of biggest festivities. Around the whole temple, in its lowest parts, one can admire a procession of saints.

The temple is dark inside. The main source of light, in accordance to hierarchy, is from under the dome. The secondary one - from the windows of the Presbyterian apse. The remaining windows and skylights are there only to illuminate the most important iconographic scenes - internal pinnacle niches with the icons of Pantocrator and the Holy Mother and the vaults of apses with icons representing biblical scenes. Only the crosses remain to be more of a symbol of light, than actual light source themselves.

Through the composition layout of the apses based on an octagon figure, their rhythm, their resemblance to semi arches of the streets of Jerusalem, the light beaming through the open apse onto the icon of Resurrection placed on the front cradle of a dimensional cross, above the Grave of Christ exemplified in the altar - all of this was supposed to be pointing towards the Passion and Resurrection play, the drama of the Jerusalem execution and the following resurrection. The first icon of the Birth of Christ, placed on the right side of the monumental scene of the Descent of Christ into the Abyss, serves as an introduction. The ending of the earthen history is the icon of Crucifixion situated on the left. Underneath one can see the icon-sculpture of Golgota, enclosing the cycle of the Jerusalem path.

In the architectural design, these are only suggested areas of history, the then gruesome Jerusalem, as a city where Jesus Christ was executed. The attempt was to convey the image through more surreal signals rather than direct reference. This was achieved through inverting the perspective and scale of the image of the particular Stations of the Cross, exemplified through the ambulatory surrounding the apses" main nave. The geometry of their concha vaults was broken, inverted and as if by accident, and temporarily supported by columns. 


\section{Church of Protection of the Holy Virgin in Bielsk Podlaski}

Another example of architecture and iconography co-existence is the Orthodox Church of Protection of The Holy Virgin in Bielsk Podlaski ${ }^{15}$. It consists of two segments. The main trunk of the temple and a free-standing belfry, connected with the temple by a glass-covered passage. Inside the belfry, on its midlevel, there is a chapel of the Annunciation of the Blessed Virgin Mary. Hidden in a myriad of nooks and crannies, it can be recognized from the outside in the eye of a rectangular opening - a semi-spherical apse concha and a Greek cross topping it.

The interior is organized traditionally, with a three segment division. It is a direct transposition of the traditional groin-dome vaul ${ }^{16}$, nine-spatial, monoapse, of the so called inscribed cross quincunx. A prototype may be found in the Byzantine temple Nea Moni Ecclesia in Constantinople, but indirect reference may be seen to the old-Russian architecture, the multiple temples of Pskov and Veliky Novgorod, with their belfries added to the trunk of the building (Fig. 14). It refers to the olden, local tradition of medieval Orthodox Church architecture school of the Grodno region, seen mostly in the orthodox church of Saints Borys and Gleb in Kołoża in Grodno (created before 1183).

A certain form of technical innovation in comparison to medieval dome design is a glazed sub-dome tambour. It resembles an old hierarchical rule of introducing light into the temple and its interaction with the iconography. Owing to great transparency of the tambour, a look into the sub-dome space is possible to see the icon of Pantocrator on the intrados (Fig. 15).

\footnotetext{
${ }^{15}$ Orthodox Parish Church of Protection of The Holy Virgin in Bielsk Podlaski - architect: Jerzy Uścinowicz; design of iconostasis Jerzy Uścinowicz; technical assistant: Tomasz Rubin; structural engineer: Waldemar Orłowski; client: Jan Szmydki, priest; design: 1998-1999; construction: 1999-2010.

${ }^{16}$ The architectural structure of the groin-dome vault, perfectly reflects the liturgical sense of the temple and according to H. Schultz: "It is the greatest depiction of the icon doctrine" (Schultz 1964: 22). In this structure, the dome sets the center of the whole composition, around which the architectonical and iconographic design is being unveiled, aspiring to expressing the "common Church" in Its structural order. On the dome around the Pantocrator and the Oranta in the apse concha, according to theological interpretation derived from Liturgy: "gathers all heavenly and earthly creature, destined to become a reborn creature in Christ, the God Human" ((after:) Leonid Uspienski, La Théologie de l'icône (...), p. 172). The whole universe "condenses" under the dome of church, over which reigns the Pantocrator, as in the words: "All authority has been given to Me in heaven and on earth" (Matthew 28: 18; Grabar 374-375.
}

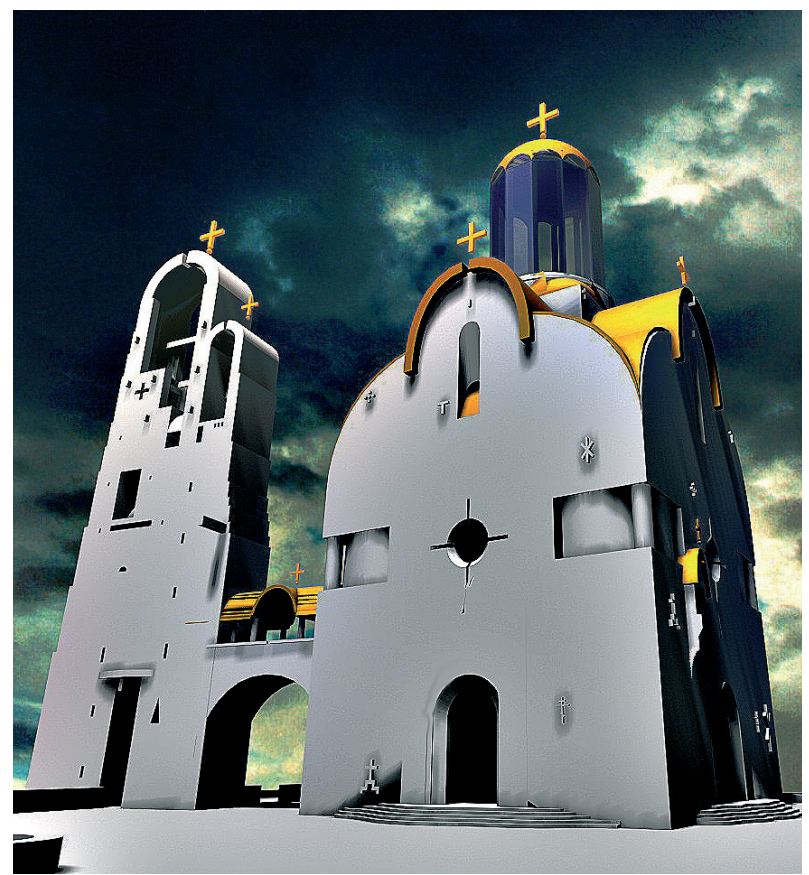

Fig. 14. Church of Protection of the Holy Virgin in Bielsk Podlaski. Project of the church. Architect's drawing

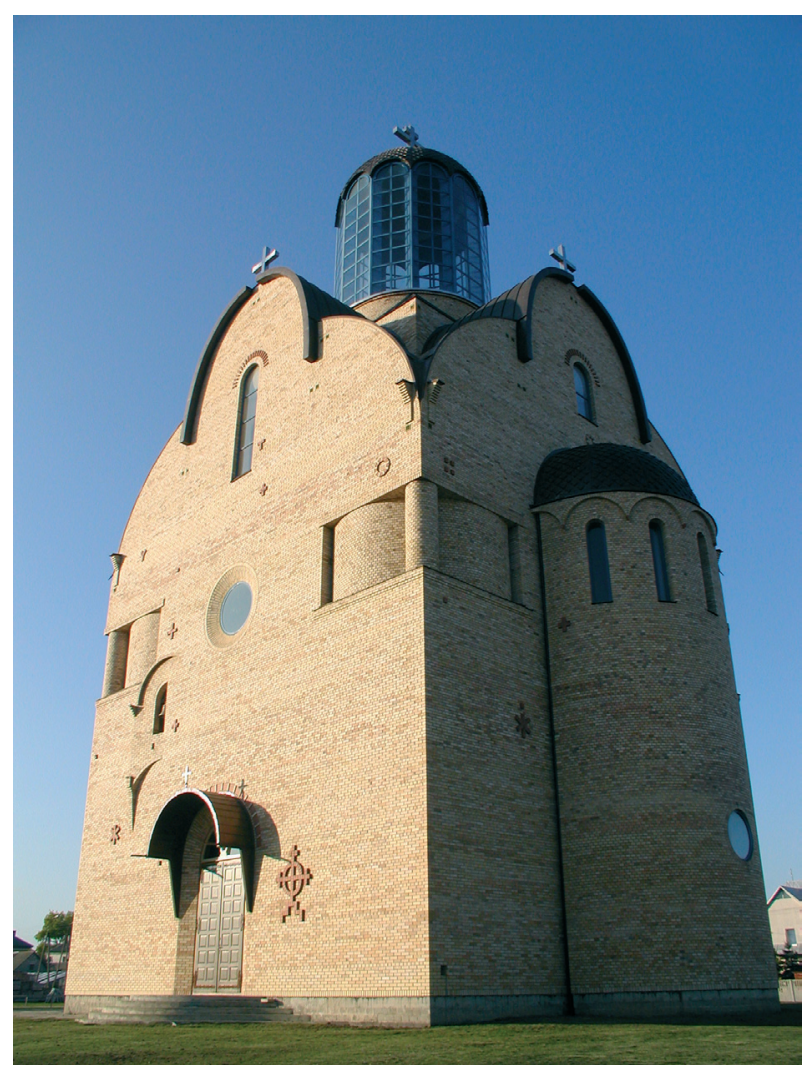

Fig. 15. Church of Protection of the Holy Virgin in Bielsk Podlaski. General view of the church from the east-south side. Realization 


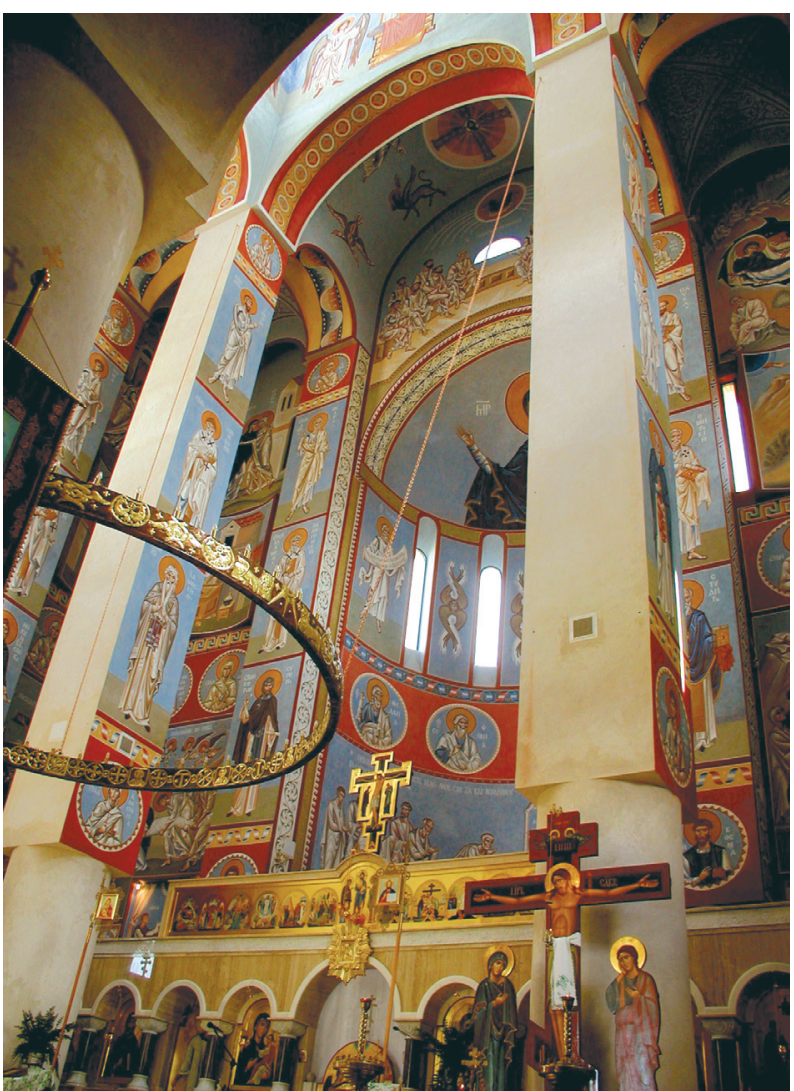

Fig. 16. Church of Protection of the Holy Virgin in Bielsk Podlaski. Interior of the church. View towards the altar and iconostasis

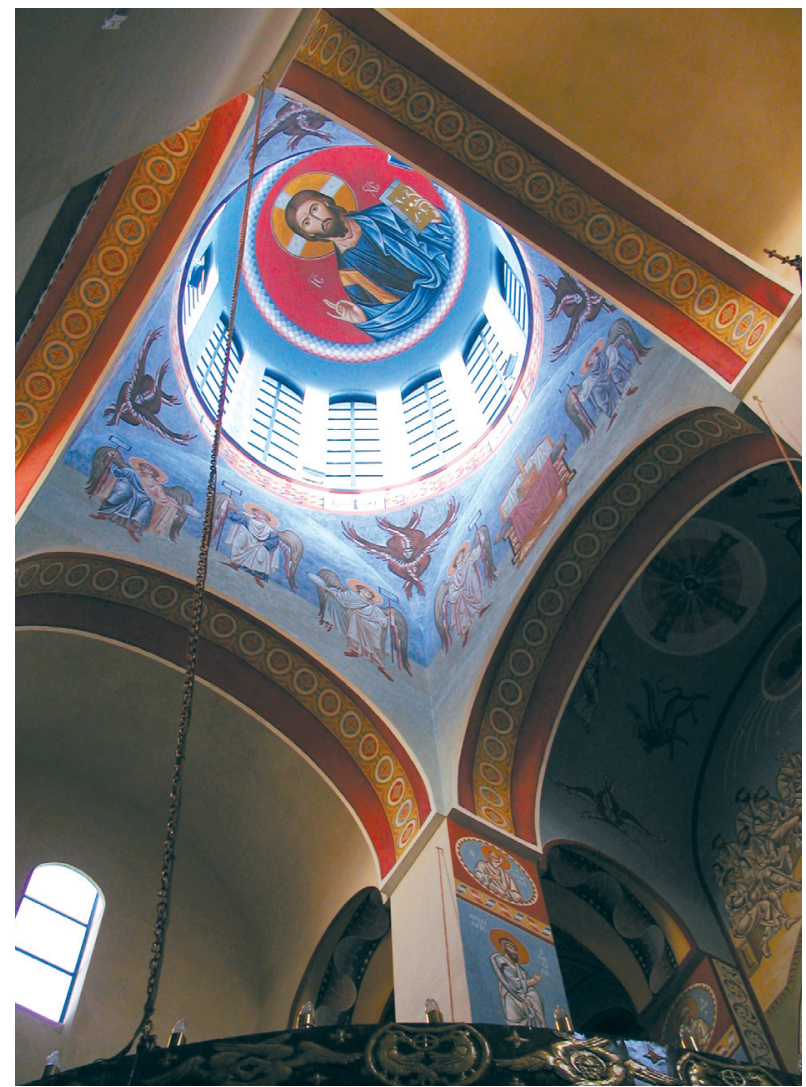

Fig. 17. Church of Protection of the Holy Virgin in Bielsk Podlaski. Interior of the church. View towards the dome structure

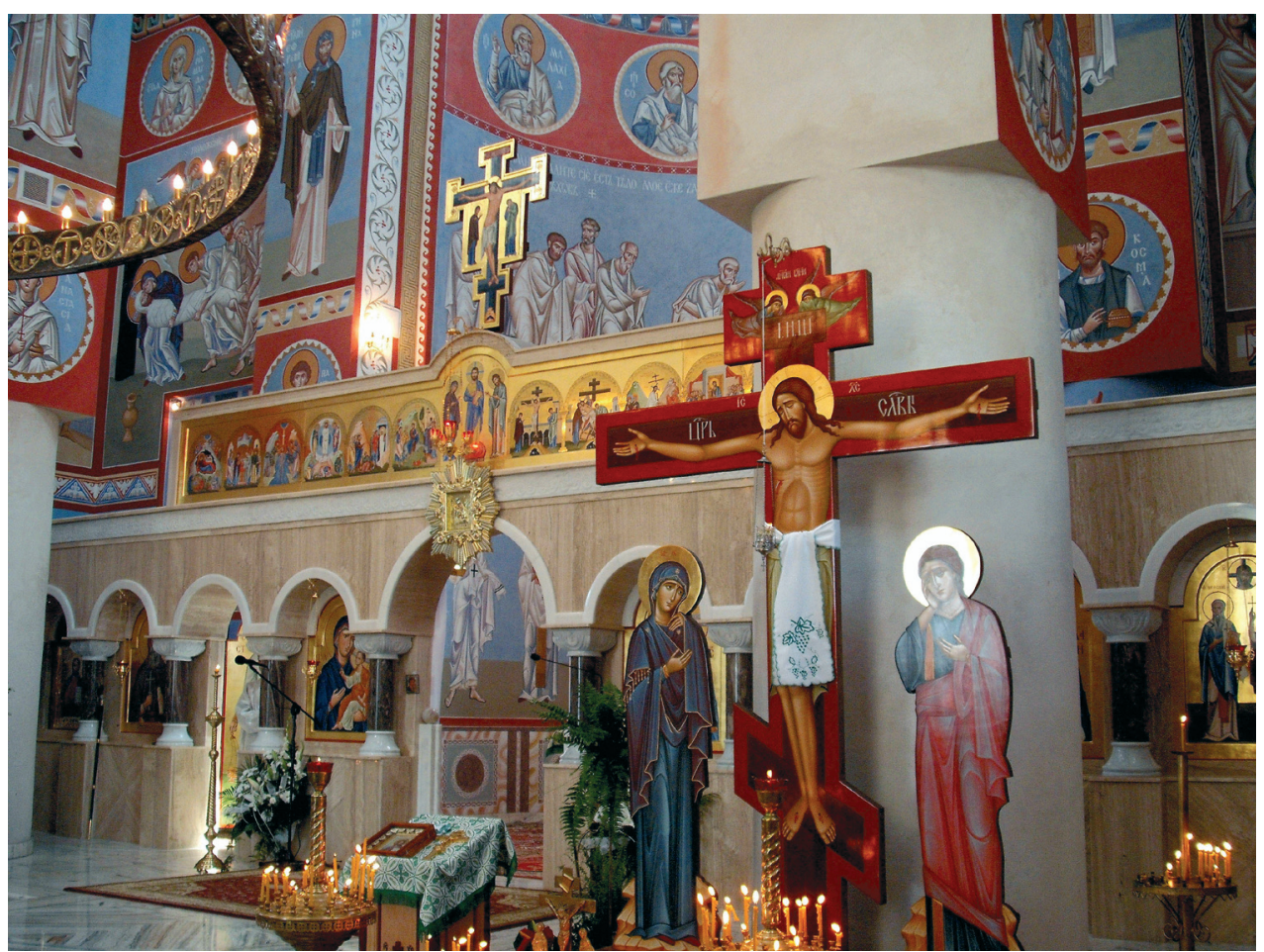

Fig. 18. Church of Protection of the Holy Virgin in Bielsk Podlaski. Interior of the church. View towards the iconostasis, crucifixion in the foreground 
An idealistic reference to the olden wlodzimierian temples are, the designed but not yet created, four corner sculptor reliefs. As in their prototypes, they are situated in mid-height of the external temple walls. In their decorative metalwork forms of copper and iron low reliefs, inspired by the metal covers of icons, they will be a symbolic image of "the life of saints in the Garden of Eden". Through reliefs of saints, bushes, paradisal trees and animals, they will be representing the image of paradise reality of the Saints, as the connection between that which is heavenly (the upper part of the temple), and that which is earthen (lower part of the temple walls).

In a similar relief art convention, a central choros panikadylion of impressive size was created ${ }^{17}$. It represents the iconic world of Saints, subtle beings, biblical symbols and signs: Old Testament - on the exterior side, and New Testament - on the interior. It is topped with a symbolic number of 56 candles, referring to the number of liturgical weeks in a year. It indicates the cosmologically temporal, cyclical and circular status of time and space within the temple. This form hosts also a whole selection of symbolological references to fire and light. It symbolizes "the Heavenly Church as a congregation (ecclesia)", "a constellation of people, enlightened by the Holy Spirit, light of faith, the ever burning fire of love of God, existing inseparably within the Heavenly Kingdom". It also constitutes the "True Light and Day" - Christ. The form of a ring, reflects also angelological, christological and cosmological meanings. It also develops this symbolism with icons of angelic hosts, iconographical images of Saints, symbols of "seven gifts of the Holy Spirit" (seven birds) and also grapevine ornaments and flowers from the Garden of Eden.

In this case, also the internal architecture of the temple is completely subordinate to iconography. It fills tightly all walls and vaults and is of a traditional structure (Fig. 16). In the apse concha resides the icon of Theotokos Oranta ${ }^{18}$ in the form of the Sign.

\footnotetext{
${ }^{17}$ Greek [panikadylion] $=$ pan (uni) + kandela (candle) - is a candlestick hanging from the dome of the church, often multi-layered, with a discus and a cross on the bottom. The most common numerical configurations of candles are 24:18:12:6 and 15:10:5 (Znosko, Mały stownik (...)).

${ }^{18}$ In the apse of a Byzantine temple symbolizing the Cave of Bethlehem, since the 9th century, an icon of the virgin Ornata was represented, later identified with the Mother of God. This icon towered over the sanctuary and the whole temple, inclining, that the temple expresses the Christian soul identifying with Paradise found (pastoral motif). When the temple did not possess a dome (in basilical settings), the top part of the apse (in the concha) was occupied by the icon of Pantocrator, and underneath the Holy Mother of God ( Evdokimov, p. 30-31; Лихачева, Лихачев 1971: 18; Ouspensky 1964).
}

Above - an icon of the Pentecost, the descent of the Holy Spirit upon the Disciples and below that, on small pillars between windows, Old Testament subtle beings - Seraphs, and underneath them a circle of Saints. Underneath the scene of Eucharist - the disciples communion is placed. Below that, in a distinctive alcove, on the "symbolic eastern door" on a "locked gate, through which only the king of Kings has passed" as a symbol of the Mother of Jesus, above the window, symbolizing "true light", "light from the East" and "the Sun of truth" (Malachi 3: 20), which will be unveiled after the second coming of Christ as Judge (Parousia) - a Mandylion, Acheiropoietos ${ }^{19}$ was inscribed. It is composed as a horizontal figure of mandorla with intricate symbolic connotations.

Below the Mandylion there is a procession of Saint Fathers of the Church of East, with its two most important creators of orthodox liturgy - Saint Basil the Great (of Caesarea) and Saint John Chrysostom in the central part, in the alcove of the "eastern door".

In a cubical well underneath the sub-dome tambour, where the rule of the "squaring of the wheel "the so called Angel's Deed was depicted, in the form of Angels and Archangels, with a central, east-facing icon of hetoimasia - the empty throne awaiting the Parousia, the second coming of Christ (Fig. 17). Above this scene, on pendentives, figures of Cherubs and Seraphs have been placed and below them, directly underneath the tambour, a ring of geometrized halfsymbols of subtle beings, the perfect messengers and links between the Absolute and the world. It is they who transmit the light of transcendence and according to the Holy Fathers of Church, the fantastic light of God's Grace is received through them, with the so called concentrated "second light" ${ }^{20}$ of God. This is mentioned by Saint Dionysius the Areopagite. The angelic hosts being the second lights bring the light of God's Grace, illuminating and protecting the temple from intrusion of the dark spirits of fallen angels. They are not corporal, so they are depicted as geometrical abstract

\footnotetext{
${ }^{19}$ It is the first and the oldest representation of Christ, not done by hand of man. In the Orthodox Church an Acheiropoietos icon is called the icon of icons. It is believed to be the image giving reason to all other religious depictions. It is the prototype and source of all other representations, as an image combining the inconceivable deity and the visible humanity of Christ. In Eastern Christian tradition, it is the grand declaration of the cult of the icon and a proof for the real Incorporation of the second personae of the Trinity.

20 "Subtle beings" or angels, are perceived in orthodox theology as the "second light", "secondary lights" and "the focus of the pure Light of God". They are saint beings, as they live in the Light of God, they are His messengers and reflection ( Evdokimov 1984: 6), and same, L"Orthodoxie, p. 258.; Św. Dionizy Areopagita, (quoted in:) Св. Дионисий Ареопагит 1848: 38-39).
} 


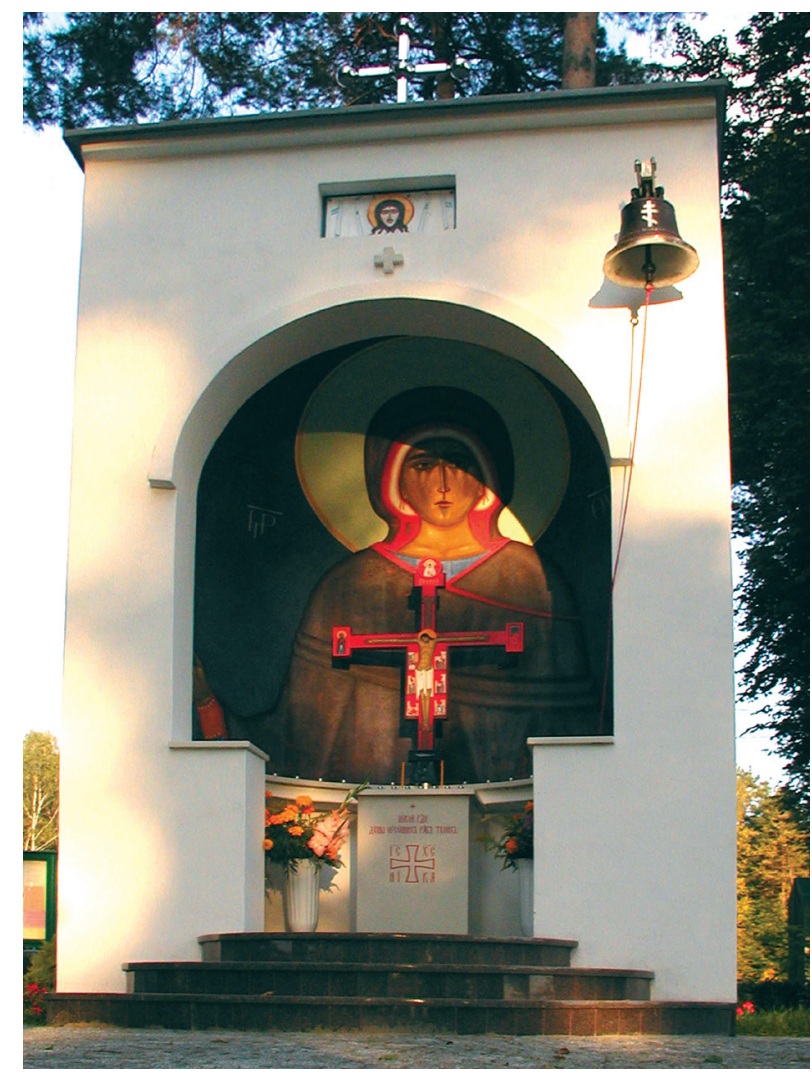

Fig. 19. Orthodox Memorial Chapel in Białystok-Dojlidy. General view of the facade

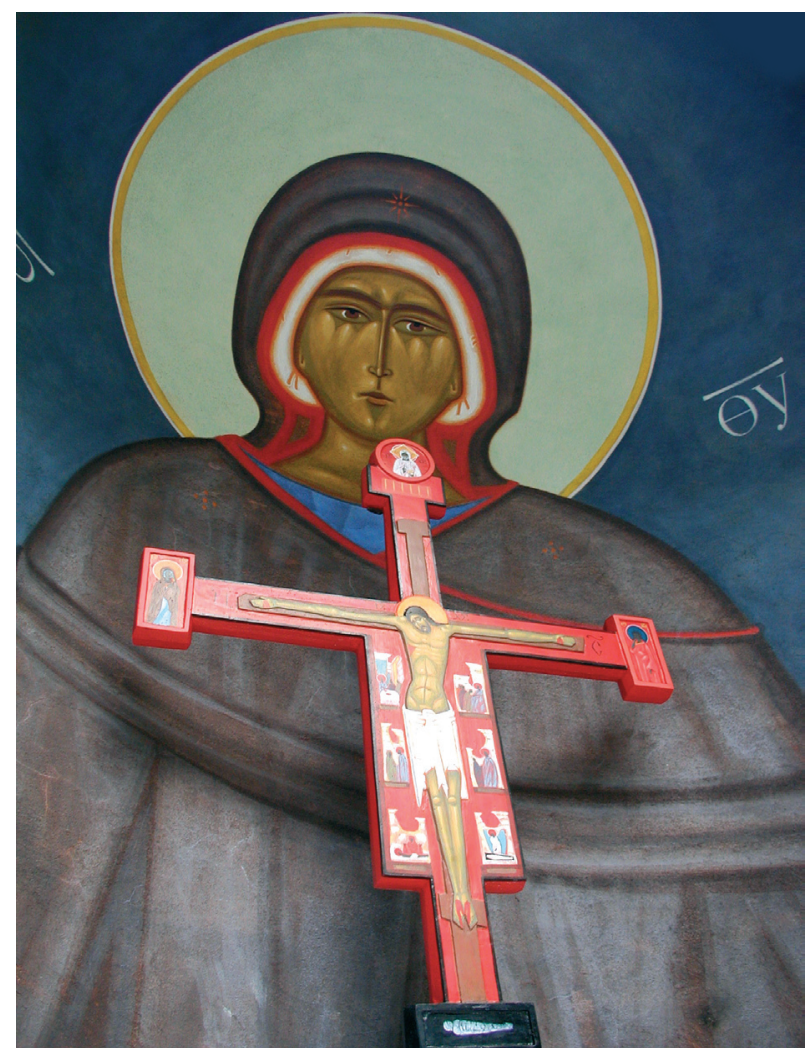

Fig. 20. Orthodox Memorial Chapel in Białystok-Dojlidy. The polychrome of a praying Theotokos Oranta in concha, crucifixion in the foreground symbols. Triangles, trapezoids and their polyphonic ${ }^{21}$ arrangements - the host of angels or angelic choirs ${ }^{22}$. Their presence in this part of the temple, directly under and above the glazed sub-dome tambour the symbol of eastern theology ideas, created and formed by figural and abstract-symbolic iconography. A form of synthesis of antique, Byzantine and free creation art form is also present here, brought on by Islam, a synthesis of both developing after the iconoclastic conflicts. The circle of angelic host surrounds the Pantocrator on His throne, emphasizing His majesty. It is He who crowns over the whole temple, marking its eschatological center.

The Pantocrator is depicted as a bust. The fingers of his hand are in process of blessing. Two - refer to the dual nature of Christ, three - symbolize the Holy Trinity. The placement of fingers resembles the Greek monogram of Christ IC XC. A halo surrounds his head, with a cross and Greek letters $\mathrm{O} \Omega \mathrm{H}$ : "I am, who I am" (Exodus 3-14) inscribed. The Pantocrator holds in his hands a closed Gospel. He is wearing a hiton, covered with a blue cloak. This icon, as a part of the canon of the Ascension of Jesus, depicting Christ taking His rightful place on the right hand side of God (Mark 16: 19), is an image of Christ present with and within us, in the meantime, the time between the Ascension $^{23}$ and Parousia. He descends upon us and we ascend with Him and through Him to God.

The iconostasis refers only partially to its primary designs. It is a resemblance more of stylistical nature, of the spatial-iconic form rather than liturgical and functional. The cooperation with the investor did not supply the desired effects. The original, not fulfilled, idea of the iconostasis, with its deacon doors, was to match the presbytery. It is more tectonic than iconic of a creation - unlike its primary design, in accordance to theological interpretation. It remained, as the design required, a balanced in scale and proportion barrier. The middle section raised upwards with a row of saints and the icon of Deesis topped with the icon

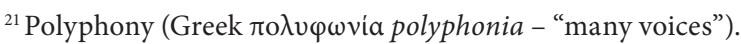

${ }^{22}$ Angelic choirs - the so called "heavenly host", the angelological personification of heavenly powers of Angels in their nine choirs: Seraphs, Cherubs, Thrones, Rulers, Superiority, Power, Force, Archangels and Angels.

${ }^{23}$ The iconography of Pantocrator - although typologically based on Old Testament visions of Isaiah 66: 1: "The heaven is My throne and the earth is My footstool" - it directly origins from the description of the Ascension of Christ in Lucas /24:50-52/ and the Acts /1:9-11/: "Now when He had spoken these things, while they watched, He was taken up, and a cloud received Him out of their sight ${ }^{10}$. And while they looked steadfastly toward heaven as $\mathrm{He}$ went up, behold, two men stood by them in white apparel, ${ }^{11}$ who also said, "Men of Galilee, why do you stand gazing up into heaven? This same Jesus, who was taken up from you into heaven, will so come in like manner as you saw Him go into heaven".
} 
of Crucifixion. This cross also links the theological message of the iconostasis with the presbytery vault paintings and firmly encapsulates the axonal iconographical composition of the temple (Fig. 18).

\section{Orthodox Memorial Chapel in Białystok-Dojlidy}

A distinctively different example of memorial art, half iconographical and hal architectural, confirming the possibility of their synthetic coexistence - with mutual submissiveness and with no dominance from either side - is the memorial kyot at the Orthodox Church of Saint Elijah the Prophet in Bialystok-Dojlidy ${ }^{24}$. It is destined as a place of thanksgiving, votive and everyday services and prayers for the casualties, murder victims or lost, who died in wars and times of repercussions. It is especially a commemoration of soldiers and civilians, which is expressed in the engraving: "To all officers and soldiers, who lay their lives for their Country and Faith" and the inscription on the analogon: „Покой, Господu душы уссопшихъ рабъ твойхъ".

The object has the status of a shrine - small commemorative form (Fig. 19). Although placed in an orthodox cemetery, it serves the memory of all soldiers who died for their Country and Faith, with no matter to their nationality, race or faith. The chapel is 2.5 fathoms high. It is oriented towards the cosmological west. Its form is expressively restrained and modest. It refers to the architecturally simple temple in its vicinity. It transfers through this, the architectural aspirations onto the iconography, inscribed into its cavern-like apse interior.

Typologically it refers to the Old Testament Arc of the Covenant (Gen. 6: 14). It resembles rock carvings of the underground temples Cappadocia, Crimea or Synai. Just as the majority of traditional temples, a polychrome of a praying Theotokos Oranta was designed in its concha (Fig. 20). Above the apse, there is a rectangular blend (niche) to the icon of Mandylion, Acheiropitos ${ }^{25}$

\footnotetext{
${ }^{24}$ Orthodox Memorial Chapel in Białystok-Dojlidy - architect, design of sculpture and polychromy: Jerzy Uścinowicz; paintings: Katarzyna Gierasimiuk; sculpture of crucifixion: Jerzy Grygorczuk; client: Mikołaj Borowik (+2008) and Anatol Fiedoruk, priests; design: 2006; construction: 2007-2008.

${ }^{25}$ The Acheiropitos icon (gr. acheimpoietos, not done by hand of man, rus. Nierukotwornyj) is an iconographical type of Christ, presenting His image on a shawl, roof tile or brick. According to tradition an image like this was imprinted miraculously by Christ Himself for king Abgar of Edessa. When the artist sent by the king could not paint Christ, the Savior himself washed his face with the shawl, imprinting His image on it. The shawl was, in times of siege, walled in in a niche over the town gate of Edessa, which in turn made a miraculous image of Christ appear on the wall (or roof tile). Christian tradition considers an image of this sort as proof of the reality of the Incarnation of the Second Personae of the Holy Trinity, and also as the most important statement of the cult of the icon.
}

depicting the image of Christ on a shawl. The chapel is topped with a Greek cross with five stigmata (seals). It is this very cross that descended into hell. According to an old Apocrypha: one Archangel led it there triumphantly, and one triumphantly so led it out.

\section{Resume}

The icon through ages of its history on earth has journeyed a long way, both through time and through space. It still does. It can be observed at present not only in Western Europe, where it is welcomed "anew" as a form of sacral communication and partly as a cult symbol and theological phenomenon. It can be observed also, though in a slightly different form, in the Christian East, where the icon experienced and still experiences certain issues. For not more than a hundred years ago, the idea of the icon was faint at most. It was even forgotten, which can be supported by examples of many. Up to this day lasts a true dispute over the icon within the Orthodox Church, between the supporters of its classical and pseudo realistic form, the true icon and its $19^{\text {th }}$ century naturalistic image. A dispute so important, for the icon is one of the visible signs of the Church's existence. It is an object of cult. It is a testimony of Incarnation and the mystery play of presence. It does not contain. It "ushers" us on the road to the heavenly Archetype. It is the path to salvation. And the path these days leads through temples.

And this, in the Orthodox Church, is where the link between the icon and architecture truly $\operatorname{lies}^{26 *}$.

\section{References}

Bułgakov, S. 1987. Prawosławie. Oczerki uczenija prawosławnoj Cerkwi, Paris.

Bułgakov, S. 1992. Prawosławie. Zarys nauki Kościoła prawosławnego, Orthdruk Białystok, Formica, Warszawa (transl. Henryk Paprocki), s. 158.

Grabar, A. 1946. Sur les images des visions théophaniques. Paris.

Evdokimov, P. 1959. L'Orthodoxie. Delachaux et Niestle S. A.

Evdokimov, P. 1964, 1986. Prawosławie (transl. Jerzy Klinger), Inst. Wyd. PAX, Warszawa.

Evdokimov, P. 1984. Sztuka ikony - teologia piękna (...), Novum 1-2: 6 .

Krug, G. 1981. Myśli o Trójcy Świętej, Novum 1-2: 29.

Ouspensky, L. 1964. The Symbolism of the Church. Oxford.

Schultz, H. J. 1964. Die byzantinische Liturgie. Fryburg im Breisgau.

${ }^{26}$ The autor asks knowledge and support of the scientific research by the KBN under the project W/WA-4/10. 
Uścinowicz, J. 2009. Exchange of values in contemporary religious architecture in Poland symbol in the dialogue between east and West, Urbanistika ir architektūra [Town Plannig and Architekture] 33 (priedas): 279-290. doi:10.3846/1392-1630.2009.33.279-290

Uspieński, L. 1987. Na putiach k jedinstwu?, Paris.

Uspienski, L. 1980. La Théologie de l'icône dans l'Eglise orthodoxe, Les Editions du Cerf.

Uspienski, L. 1991. Teologia ikony. Wyd. „W Drodze”, Poznań.

Znosko, A. 1983. Mały słownik wyrazów starocerkiewno-słowiańskich i terminologii cerkiewno-teologicznej, CHAT, Warszawa.

Лихачева, В.; Лихачев, В. 1971. Художественное наследие древней Руси и современность. Ленинград: Изд-во „Наука”.

Св. Дионисий Ареопагит, 1848. О Небесной Иерархии, 3 гл, IX(2): 38-39. Москва.

Трубецкой, Е. 1976. Умозрение в красках. Москва.

\section{NAUJAS IKONŲ GYVENIMAS ARCHITEKTŪROJE: PRITAIKYMAS AR SINTEZĖ?}

\section{J. Uścinowicz}

Santrauka. Nuo seno Lenkija yra kultūrinis ir religinis paribys. Tai erdvé, kur susilieja Vakarų lotyniškoji Romos katalikų kultūra ir Rytų graikiškoji bei slaviškoji Ortodoksų kultūra. Ši erdvè itin įdomi siekiant atlikti Vakarų ir Rytų bažnyčių meno lyginamają analizę. Straipsnyje nagrinejjami išskirtiniai pastarojo dešimtmečio Lenkijos architektūros, ikonografijos ir teologijos sąveikos šiuolaikiniame sakraliniame mene pavyzdžiai. Čia taip pat atskleidžiamas tradicinių erdvinių ir funkcinių struktūrų raidos bei ikonografinès tradicijos kaitos Ortodoksų bažnyčioje procesai. Tyrime svarstomi meno ir svarbiausių naujų ideologinių simbolių bei liturgijos tipų klausimai. Darbe identifikuojami kūrinių ir projektų požymiai tampa pagrindu juos klasifikuoti kaip tradicinius. Čia pateikiamas menų sintezès vertinimas laikytas priemone kurti liturginès paslapties išraišką Ortodoksų bažnyčiai. Ar taip yra iš tiesų - paliekama spręsti skaitytojui.

Reikšminiai žodžiai: ikonografija, sakralinė architektūra, simbolizmas, stačiatikiai, šventykla, tradicija, inovacija, sintezè.

\section{JERZY UŚCINOWICZ}

Prof Dr Habil, Eng, Arch. Head of Department of Public Utility Architecture, Faculty of Architecture of Balystok University of Technology.E-mail: jus@pb.edu.pl

$\mathrm{He}$ is an author of over 80 scientific publications: two monograph, 2 books (as a co-author) and 80 articles, mainly about a sacral architecture of cultures dwelling on the border. He is an author or a co-author of over 52 architecture designs, principally public utilities architecture. He has designed 26 sacral buildings and complexes (13 temples are in realization now). They are mainly orthodox and Roman Catholic churches, monasteries, parish ensembles, memorial complexes and chapels. He has taken part in over 30 architectural national and international competitions and biennales of architecture and garnered 13 prizes and distinctions. He was a director or coordinator of the 13th research projects. He presented 62 papers at international scientific conferences. He is an author of 28 individual exhibitions of sacral architecture. He was an organizer and co-organizer of the following international conferences: "Architecture of Local Cultures Borderland" in 2003 and 2009), conferences "Sacred and Monumental Buildings" (6 editions) and "Congress of Polish Architect in Białystok" in 2005. He has been a member of the Committee of Architecture and Urban Planning of the Polish Academy of Sciences, a director of the UIA Working Program "Spiritual Places", a board member of the Association of Polish Architects SARP, the chairman of the Regional Council of the Conservation in Podlasie region in Poland and a board member of the Care of Monuments of the Sacred Art Committee. He was awarded the first individual prize of the Ministry of National Education in 1998, Ministry of Administration and the President of the Housing and Cities Development Prize in 1998, the Prince Ostrogsky Prize in 2000, the St. Mary Magdalene Prize in 2010 and the prestigious St. Brother Albert Price in 2005 for his outstanding contributions in science and sacred art. 